\title{
Spontaneous Rupture of Proximal Ureter: A Case Report
}

\author{
Spontane Proksimal Üreter Rüptürü: Olgu Sunumu
}

\author{
(1) İlke Onur Kazaz, (1) Ahmet Serdar Teoman, (1) Fatih Çolak, (1) Rasin Özyavuz \\ Karadeniz Technical University Faculty of Medicine, Department of Urology, Trabzon, Turkiye
}

\begin{abstract}
Spontaneous non-traumatic urinary collecting system ruptures without distal obstructive causes are rare and uncommon. They should be considered in the differential diagnosis of renal colic or acute abdomen. Here, we present a case of spontaneous rupture of the left proximal ureter with perirenal fluid extravasation without an identified cause. The patient was treated conservatively and in the first week, symptom improvement was shown by control imaging methods. Ureteral stent placement or percutaneous nephrostomy, even open surgery are options for the management of spontaneous rupture of the urinary collecting system, however, conservative management may be an option for selected patients.
\end{abstract}

Keywords: Rupture, Ureter, Collecting system, Spontaneous

\section{Öz}

Distal obstrüktif nedenlere bağlı olmayan, spontane, travmatik olmayan üriner toplayıcı sistem rüptürleri nadir görülmektedir. Ayırıcı tanıda akut abdomen ve renal kolik nedenler göz önünde bulundurulmalıdır. Burada, nedeni bilinmeyen perirenal sıvı kaçağıyla gözlenen sol proksimal üreter spontan rüptürü olgusunu sunmaktayız. Hastaya konservatif tedavi verilerek tedavisinin ilk haftasında semptomlarında iyileşme gözlendi. Üriner toplayıcı sistem rüptürlerinde tedavi olarak üreteral J stent yerleştirilmesi, perkütan nefrostomi uygulanması, hatta cerrahi bir seçenek iken; konservatif tedavi de seçilmiş hastalarda bir tedavi yöntemi olabilir.

Anahtar Kelimeler: Rüptür, Üreter, Toplayıcı sistem, Spontane

\section{Introduction}

Urinary collecting system ruptures are uncommon and are often due to distal obstructive conditions such as urinary stones or external mass pressure to the ureter. However, in the literature, spontaneous non-traumatic urinary collecting system ruptures with perinephric fluid extravasation without distal obstructive causes have been reported $(1,2)$. Here, we present a case of spontaneous rupture of the left proximal ureter without an identified cause.

\section{Case Presentation}

A 65-year-old female patient was admitted to the emergency room due to severe left flank pain, which aroused her from sleep. There was no history of trauma affecting the left lumbar region.
She never had urinary stone disease. In addition, no history of operation or comorbidity was noted. Her physical examination was normal except left costovertebral angle tenderness. The mere pathological laboratory findings were leukocytosis $(12960)$ $\mathrm{uL})$ and an increase in erythrocyte sedimentation rate $(22 ; \mathrm{N}$ : 0-20 mm/hour). Contrast-enhanced computed tomography (CT) of the abdomen showed a perfusion reduction in the left renal parenchyma, with a collection of fluid causing perirenal reticular density suggesting urinoma. CT urography showed contrast agent extravasation from the left proximal ureter and contrast material accumulation around the perirenal area. There was no sign of obstruction. A consent form had been taken when she was hospitalized, and followed up conservatively. In the first week, control abdominal imaging methods showed disappearance of perirenal reticular density. Eventually, she did not need any surgical intervention.

Correspondence: Ahmet Serdar Teoman MD, Karadeniz Technical University Faculty of Medicine, Department of Urology, Trabzon, Turkiye Phone: +90 4623775858 E-mail: asteoman88@gmail.com ORCID-ID: orcid.org/0000-0003-4592-9748

Received: 27.04.2018 Accepted: 11.06.2018

Cite this article as: Kazaz iO, Teoman AS, Çolak F, Özyavuz R. Spontaneous Rupture of Proximal Ureter: A Case Report. J Urol Surg 2019;6(1):74-75.

${ }^{\circ}$ Copyright 2019 by the Association of Urological Surgery / Journal of Urological Surgery published by Galenos Publishing House. 


\section{Discussion}

Spontaneous rupture of the urinary collecting system is a rare condition. Some hypothesis for the mechanisms of spontaneous urinary collecting system ruptures, such as urinary stone movement causing internal ureteral erosion for distal urinary stones, have been proposed (3). Besides, there are some reported cases of spontaneous ureteral rupture due to malignancies $(4,5)$ and pregnancy (6).

The term "spontaneous" for urinary collecting system ruptures was defined in a study as being with no external trauma, no cystoscopic ureteral manipulation, no external compression or any urinary surgical intervention (7). As defined, there was no underlying cause for a ureteral rupture in our case.

There is no specific clinical manifestation for spontaneous rupture of the urinary collecting system. Sudden onset of flank pain, mimicking renal colic symptoms, or acute abdomen might be the main symptoms (8).

Despite the rupture level in the urinary system may vary, the most commonly described site is the renal fornix (9). The rupture level of ureteropelvic junction or proximal ureter level is rare. The cause of rupture is the increase of intraluminal pressure by external or internal obstruction of the ureter. Urinary system ultrasonography may show hydronephrosis and perinephric fluid. Contrast-enhanced CT and CT urography may be the best diagnostic imaging methods for urinary collecting system ruptures (10).

Spontaneous urinary collecting system ruptures may cause major consequences, such as urinoma, perirenal abscess formation, and urosepsis. Ureteral JJ stent placement, percutaneous nephrostomy, or even surgical repair such as urinary diversion may be required for treatment. However, in selected cases, observation and conservative management may be an option. Akpinar et al. (11) reported four patients with the complaint of sudden onset abdominal and flank pain. All patients had urinary extravasation on their CT scans. One patient underwent ureteral stent placement, and the rest of them were followed conservatively. Perirenal fluid resolution was seen on CT images within three days. The patients were followed for a mean period of 17 months without any problems (11). Al-mujalhem et al. (12) declared that conservative management was a valid option for non-complicated spontaneous renal forniceal rupture.

Spontaneous urinary collecting system rupture should be considered in emergency rooms in the differential diagnosis of renal colic or acute abdomen. There is no evidence yet for the best treatment option, however, conservative management may be an option for selected cases besides other invasive treatment methods. All cases should be reported in order to expand the patient pool and further literature data is needed to determine the most appropriate treatment modality.

\section{Ethics}

Informed Consent: Written informed consent was obtained from the patient.

Peer-review: Externally peer-reviewed.

\section{Authorship Contributions}

Surgical and Medical Practices: I.O.K., A.S.T., F.Ç., R.Ö., Concept: I.O.K., A.S.T., R.Ö., Design: I.O.K., A.S.T., R.Ö., Data Collection or Processing: I.O.K., A.S.T., Analysis or Interpretation: I.O.K., A.S.T., F.Ç., R.Ö., Literature Search: I.O.K., A.S.T., F.Ç., R.Ö., Writing: i.O.K., A.S.T., F.Ç., R.Ö.

Conflict of Interest: No conflict of interest was declared by the authors.

Financial Disclosure: The authors declared that this study received no financial support.

\section{References}

1. Aggarwal G, Adhikary SD. Spontaneous ureteric rupture, a reality or a faux pas? BMC Urol 2016;16:37.

2. Eken A, Akbas T, Arpaci T. Spontaneous rupture of the ureter. Singapore Med J 2015;56:29-31.

3. Liu S-Y, Lin J-N, Huang C-Y, Tsai IT. Spontaneous rupture of the ureter mimicking acute appendicitis: Two case reports. Journal of Acute Medicine $2011 ; 1: 61-63$.

4. Inahara $\mathrm{M}$, Kojima S, Takei $\mathrm{K}$, Naito H, Kito H, Yamazaki K, Ishida Y, Furuya $\mathrm{Y}$. Two cases of spontaneous rupture of upper urinary tract caused by the primary ureteral or renal pelvic tumor: a case report. Hinyokika Kiyo 2009;55:31-34.

5. Yoshii T, Horiguchi A, Shirotake $S$, Tobe $M$, Hayakawa $M$, Sumitomo $M$, Asano T. [Spontaneous rupture of the ureter as the primary symptom of malignant lymphoma]. Hinyokika Kiyo 2010;56:639-643.

6. Matsubara S, Morita T, Saito Y, Sato S, Suzuki M. Non-traumatic rupture of the left upper urinary tract during pregnancy without discernable underlying disorders. Arch Gynecol Obstet 2010;282:111-113.

7. Schwartz A, Caine M, Hermann G, Bittermann W. Spontaneous renal extravasation during intravenous urography. Am J Roentgenol Radium Ther Nucl Med 1966;98:27-40.

8. Chen $\mathrm{GH}$, Hsiao PJ, Chang $\mathrm{YH}$, Chen $\mathrm{CC}$, Wu HC, Yang CR, Chen $\mathrm{KL}$, Chou $\mathrm{EC}$, Chen WC, Chang $\mathrm{CH}$. Spontaneous ureteral rupture and review of the literature. Am J Emerg Med 2014;32:772-774.

9. Gershman B, Kulkarni N, Sahani DV, Eisner BH. Causes of renal forniceal rupture. BJU Int 2011;108:1909-1911.

10. Yanaral F, Ozkan A, Cilesiz N, Nuhoğlu B. Spontaneous rupture of the renal pelvis due to obstruction of pelviureteric junction by renal stone: A case report and review of the literature. Urol Ann 2017;9:293-295.

11. Akpinar H, Kural AR, Tüfek I, Obek C, Demirkesen O, Solok V, Gürtug A. Spontaneous Ureteral Rupture: Is Immediate Surgical Intervention Always Necessary? Presentation of Four Cases and Review of the Literature. J Endourol 2002;16:179-183.

12. Al-mujalhem AG, Aziz MS, Sultan MF, Al-Maghraby AM, Al-Shazly MA. Spontaneous forniceal rupture: Can it be treated conservatively? Urol Ann 2017;9:41-44. 